\section{The Metric System and British Export Trade}

Presidivg at a lecture by the Rev. A. J. Stubbs, vice-chairman of the Decimal Association, at the Institute of Export on December 14, Sir Isidore Salmon, M.P., declared that British industry could save large sums of money internally, and increase international trade by millions of pounds a year, if Britain cared to adopt the metric system. "It is unbelievable," he said, "that our own Government has virtually ignored the decimal and metric systems, which are employed by every one of our foreign competitors and many of our Colonies and Dominions. We should in our own interest do all we can to bring before the Government the urgent necessity of appointing a committee to inquire into the whole question." Mr. Stubbs, who before he was ordained, was an electrical and civil engineer, said that of our oversea trade, 64 per cent went to decimalized coinage countries, including about one third of our British oversea markets. The importance of the metric system was also plain, he said, when it was realized that for export purposes we had to manufacture different sizes of machined products, other goods or cartons, and effect intricate internal calculations. It might be said that, to improve export trade, our first duty was to adopt the metric system with its internationally agreed and unalterable values. Mr. Stubbs mentioned that among the influential supporters of a British metric system and decimal coinage were the British Chamber of Commerce, the International Chamber of Commerce, the Federation of British Industries, the Trade Union Congress General Council and the National Association of Head Teachers.

\section{History of Science}

The October number of the Annals of Science, a quarterly journal dealing with the history of science, published by Messrs. Taylor and Francis, contains some papers of unusual interest. Prof. J. R. Partington and Dr. D. McKie contribute the first part of their historical studies on the phlogiston theory, dealing with the levity of phlogiston. This theory had a most important influence on the development of chemistry, yet its history is in many ways defective. Prof. Partington and Dr. McKie have made a very detailed and thorough study of the original sources, and show how the idea of the levity of phlogiston developed and what forms it took during the second half of the eighteenth century. Particular attention is given to the views of Guyton de Morveau, a portrait of whom is prefixed to the issue of the Annals. Prof. Marjorie Nicolson and Prof. Nora M. Mohler contribute a very interesting study of Swift's "Voyage to Laputa", in which they show how carefully Swift read the contemporary scientific literature and how skilfully he was able to make use of it in his own writings. There are also interesting papers on views concerning the nature of heat and cold, on aqueous vapour and evaporation, on the teaching of the history of science in a women's college in America, and on the Chemical Society of Glasgow.

\section{Early Astronomical Instruments at Oxford}

Axthough a manuscript of 1697 in the Bodleian Library has provided an inventory of the instruments belonging to the early Savilian professors, it is only quite recently that certain of these instruments were discovered to be still in existence and within the walls of the University Observatory itself. In the Observatory of July, p. 190, Dr. R. T. Gunther describes four instruments which have been reassembled from "certain old metal bars and plates" found behind some cases in the University Observatory and brought to the notice of Dr. Gunther by Prof. H. H. Plaskett. These newly discovered instruments are : (1) a 14-in. astrolabe made by Thomas Gemini in 1559 for Queen Elizabeth; (2) a mural quadrant of $6 \mathrm{ft} .9$ in. radius made in 1637 by Elias Allen; (3) a 6-ft. iron sextant with brass limb, to be attributed possibly to Elias Allen; and (4) an equatorial quadrant of $2 \mathrm{ft}$. radius of which the maker is uncertain. In describing these interesting instruments, Dr. Gunther directs attention to the high excellence of Allen's work as instanced by the mural quadrant of 1637 , which he divided to give direct readings to $2^{\prime}$ and, by means of a diagonal scale, to $12^{\prime \prime}$. It is suggested that these instruments were installed by Bainbridge, the first Savilian professor, on whose death they passed as his private property to his successor, John Greaves ; in 1659, seven years after the death of John Greaves, the instruments appear to have been given to Oxford by his brother, Nicolas Greaves, in memory of the first two Savilian professors.

\section{Grass Drying}

THE development of grass drying since 1927 was discussed by Dr. R. E. Slade in a lecture given to the Institution of Chemical Engineers on December 17. Progress has been remarkable and further advance depends on reducing capital and running costs, designing a plant suitable for small farmers, and improving management so as to ensure a continuous and reasonably steady supply of grass during the growing season. The best plants to-day, said Dr. Slade, can produce high-protein dried grass at an overall cost of $£ 5$ a ton, including obsolescence, and this cost compares favourably with that of feeding cakes at the present time. Dr. Slade has recently been experimenting with a simple, inexpensive dryer, workable by one man and suitable for a farm with 50-100 acres of grassland. A single fixed tray, $15 \mathrm{ft}$. long, $7 \mathrm{ft}$. wide, with a deep bed of $2 \frac{1}{2} \mathrm{ft}$., is charged with grass to a depth of $2 \mathrm{ft}$. The grass is held down with a hurdle, covered with Hessian, and heated by furnace gases at $120^{\circ} \mathrm{C}$. for $1 \frac{1}{2}$ hours; it shrinks 10-12 inches, more grass is added, and the heating is repeated for a like time. The grass, now nearly dry, is tedded and then heated again for 45 minutes. The average air-cycle efficiency during the 4 hours' heating is 76 per cent, and the weight of water evaporated, in a two-day test, was 7.6 cwt. for each cwt. of coke burned. This simple and inexpensive dryer is to be tested further during the coming year. 